\title{
Development of the Medical Information System for the Treatment of Hepatitis B Virus
}

\author{
Seong-Ran Lee ${ }^{1 *}$ \\ ${ }^{1 *}$ Department of Medical Information, Kongju National University, Chungnam, Republic of Korea, \\ leesr@kongju.ac.kr ${ }^{1}$
}

Article History: Received: 11 January 2021; Accepted: 27 February 2021; Published online: 5 April 2021

\begin{abstract}
This study is to develop a medical information system for the treatment of hepatitis B virus.The study surveyed 154 people who visited the internal medicine department of the general hospital from August 5, 2019 to October 21, 2019 in the C area. The data were surveyed and interviewed.. . The general characteristics of the subjects were used by chi-square test. The change in patient condition was analyzed as t-test following the application of the information system. The results of this study are as follows. First, it was found that eating sprout barley after applying the information system was significantly higher than before the system was applied(t=-4.16, $\mathrm{p}<.01)$.. Second, liver disease has decreased since the 6th day of application of information system applied information system. However, liver disease has been on the rise again since the $18^{\text {th }}$ This paper means its influence by accepting a specific strategic performance approach. The findings from the study confirmed that this information system is effective.
\end{abstract}

Keywords:Medical information system, Treatment, Hepatitis B virus, Sprout barley

\section{Introduction}

Hepatitis B virus is a virus that can be life-threatening by infecting the liver. It is infected by body fluids such as blood infected with hepatitis B virus.Chronic B-type viral liver diseases are is a condition in which infections last more than six months and chronic inflammation of the liver persists[1],[2],[3]. One of the biggest causes of death for adult men in their 40s in Korea is hepatitis B virus.It is mostlydue to hepatitis B virus. Most cases of liver cirrhosis or liver cancer also stem from hepatitis B.The number of hepatitis A patients per 100,000 people also increased by 2.24 from 4.70 last year to 6.94 this year. It can easily cause fatigue, loss of appetite, nausea, vomiting, muscle pain, and fever.

If the urine is darkened or severe, it can even lead to jaundice in which the skin or eyes turn yellow[4],[5],[13].This situation can repeat the recovery and deterioration. This can lead to serious complications such as liver cirrhosis and liver cancer.It is important to manage chronic viral liver disease before proceeding with this serious liver disease[6],[7],[12]. Therefore this study is to develop a medical information system for the treatment of hepatitis B virus.The development of the information system is to improve the treatment performance and patient satisfaction of hepatitis B patients.

One of the biggest causes of death for adult men in their 40s in Korea is hepatitis B virus.It is mostly due to hepatitis B virus. Most cases of liver cirrhosis or liver cancer also stem from hepatitis B.The number of hepatitis A patients per 100,000 people also increased by 2.24 from 4.70 last year to 6.94 this year. It can easily cause fatigue, loss of appetite, nausea, vomiting, muscle pain, and fever.

If the urine is darkened or severe, it can even lead to jaundice in which the skin or eyes turn yellow[4],[5].This situation can repeat the recovery and deterioration. This can lead to serious complications such as liver cirrhosis and liver cancer.It is important to manage chronic viral liver disease before proceeding with this serious liver disease[6],[7].

Therefore this study is to develop a medical information system for the treatment of hepatitis B virus.The development of the information system is to improve the treatment performance and patient satisfaction of hepatitis B patients.

\section{Material and Methods}

\subsection{Steps for Building A New Information System}

The steps for building a new information system are as follows1) Overall design phase of information system 2) Data application and analysis3) Model evaluation of information system 4) Stage of improvement in the liver condition of a patient in Figure 1.

\subsection{Materials and Method}

The study surveyed 154 people who visited the internal medicine department of the general hospital from August 5, 2019 to October 21, 2019 in the $\mathrm{C}$ area. The group of people who mediated the information system was classified as 77 people and those who did not mediated the information system were classified as 77 people.The data were surveyed and interviewed.The general characteristics of the subjects were used by chisquare test. The change in patient condition was analyzed as t-test following the application of the information system. 


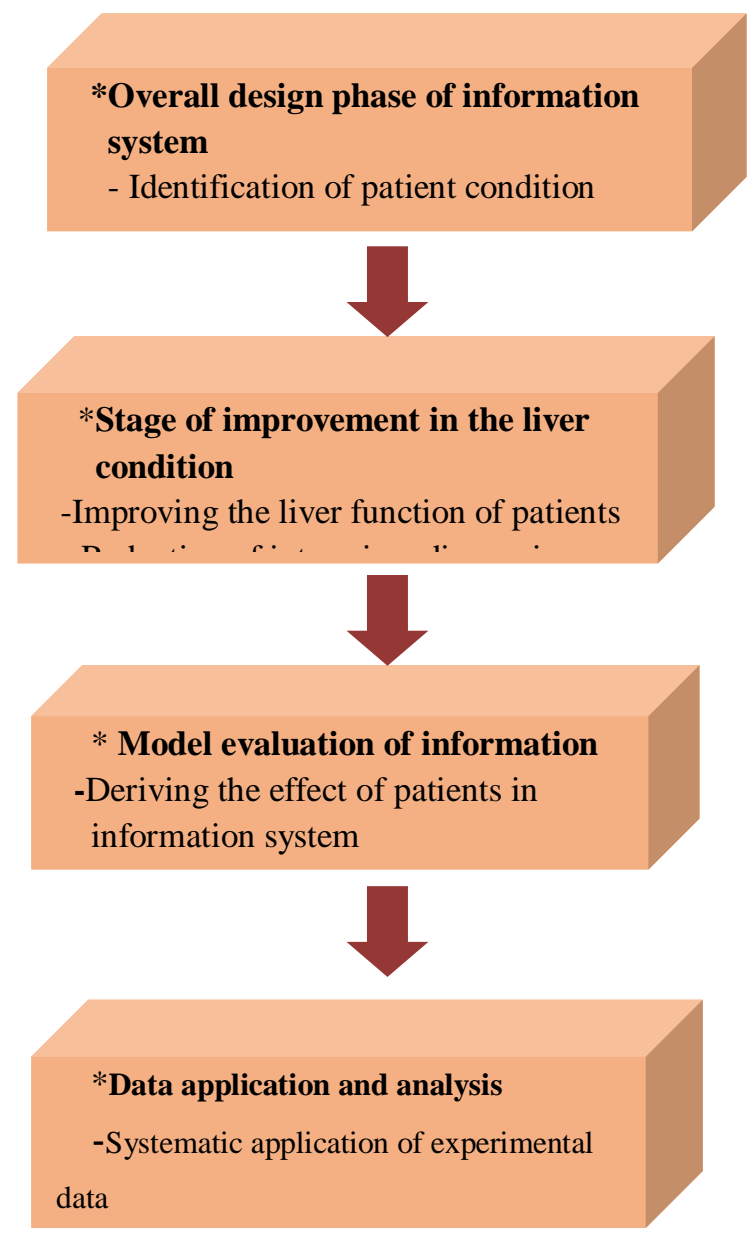

\section{Result}

Fig. 1Establishment of a New Information System to Prevent Hepatitis B Virus

\subsection{General Characteristics of Subjects in This Study}

Table 1 was derived general characteristics of subjects in this study. According to gender,men had $58.4 \%$ of the experimental group higher than $46.8 \%$ of the control group. $49.4 \%$ of the experimental group over 60 years of age were significantly higher than $35.1 \%$ of control group. $27.3 \%$ of experimental group with a family history of hepatitis B disease were significantly higher than $13.0 \%$ of the control group $\left(X^{2}=2.84, p<.05\right)$.

Table 1. General Characteristics of Subjects in This Study

\begin{tabular}{|c|c|c|c|}
\hline \multirow[t]{2}{*}{ Variables } & $\begin{array}{l}\text { Experi } \\
\text { mental } \\
\text { group }\end{array}$ & $\begin{array}{l}\text { Contro } \\
\text { I group. }\end{array}$ & \multirow[t]{2}{*}{$\mathbf{X}^{2}$} \\
\hline & $\mathbf{N}(\%)$ & $\mathbf{N}(\%)$ & \\
\hline \multicolumn{4}{|l|}{ Gender } \\
\hline Men & $\begin{array}{c}45(58.4 \\
)\end{array}$ & $\begin{array}{c}36(46.8 \\
)\end{array}$ & 4.16 \\
\hline Women & $\begin{array}{l}32(41.6 \\
)\end{array}$ & $\begin{array}{c}41(53.2 \\
)\end{array}$ & \\
\hline \multicolumn{4}{|l|}{ Age } \\
\hline$\leq 49$ & $\begin{array}{c}13(16.9 \\
)\end{array}$ & $\begin{array}{c}19(24.7 \\
)\end{array}$ & 11.73 \\
\hline $50-59$ & $\begin{array}{c}26(33.8 \\
)\end{array}$ & $\begin{array}{c}31(40.3 \\
)\end{array}$ & \\
\hline
\end{tabular}


Seong-Ran Lee ${ }^{1 *}$

\begin{tabular}{|c|c|c|c|}
\hline$\geq 60$ & $\begin{array}{c}38(49.4 \\
)\end{array}$ & $\begin{array}{c}27(35.1 \\
)\end{array}$ & \\
\hline \multicolumn{4}{|l|}{$\begin{array}{l}\text { Marital } \\
\text { status }\end{array}$} \\
\hline Married & $\begin{array}{c}52(67.5 \\
)\end{array}$ & $\begin{array}{l}58(75.3 \\
)\end{array}$ & 8.59 \\
\hline Unmarried & $\begin{array}{c}16(20.8 \\
)\end{array}$ & $\begin{array}{c}12(15.6 \\
)\end{array}$ & \\
\hline $\begin{array}{c}\text { Separation/ } \\
\text { divorce }\end{array}$ & $9(11.7)$ & $7(9.1)$ & \\
\hline \multicolumn{4}{|l|}{$\begin{array}{l}\text { Family } \\
\text { history }\end{array}$} \\
\hline Yes & $\begin{array}{c}21(27.3 \\
)\end{array}$ & $\begin{array}{l}10(13.0 \\
)\end{array}$ & $2.84 *$ \\
\hline No & $\begin{array}{c}56(72.7 \\
)\end{array}$ & $\begin{array}{l}67(87.0 \\
)\end{array}$ & \\
\hline \multicolumn{4}{|l|}{$\begin{array}{l}\text { Alcohol } \\
\text { drinking }\end{array}$} \\
\hline Yes & $\begin{array}{c}34(44,2 \\
)\end{array}$ & $\begin{array}{c}22(28.6 \\
)\end{array}$ & $1.73^{*}$ \\
\hline No & $\begin{array}{c}43(55.8 \\
)\end{array}$ & $\begin{array}{l}55(71.4 \\
)\end{array}$ & \\
\hline Total & $\begin{array}{l}77(100 . \\
0)\end{array}$ & $\begin{array}{l}77(100 . \\
0)\end{array}$ & \\
\hline
\end{tabular}

3.2 Changes in Patients According to theApplication of Information System

Table 2shows changes in patients depending on whether the information system is applied or not. It was found that eating sprout barley after applying the information system was significantly higher than before the system was applied $(\mathrm{t}=-4.16, \mathrm{p}<.01)$

Table 2. Changes in PatientsAccording to theApplication of Information System

\begin{tabular}{|c|c|c|c|}
\hline \multirow[b]{2}{*}{$\begin{array}{l}\text { Items } \\
\text { / }\end{array}$} & Before & After & \multirow[b]{2}{*}{$\mathbf{t}$} \\
\hline & D $\begin{array}{l}\text { Mean } \pm \text { S. } \\
\text { D }\end{array}$ & S.D $^{\text {Mean } \pm}$ & \\
\hline sprout barley & $38^{16.85 \pm 1}$ & $1^{39.28 \pm}$ & $\begin{array}{c}- \\
4.16^{* *}\end{array}$ \\
\hline Onion intake & $95^{24.67 \pm 3 .}$ & $4^{4.82^{46.03 \pm}}$ & $\begin{array}{c}- \\
1,85^{* *}\end{array}$ \\
\hline $\begin{array}{l}\text { Shoulder } \\
\text { pressure }\end{array}$ & $48^{29.31 \pm 0 .}$ & $0^{48.25 \pm}$ & $\begin{array}{l}3.2 \\
9 * *\end{array}$ \\
\hline $\begin{array}{l}\text { Pineapple } \\
\text { intake }\end{array}$ & $75^{31.49 \pm 1 .}$ & $\begin{array}{c}43.83 \pm \\
1.75\end{array}$ & $\begin{array}{c}- \\
1.94 *\end{array}$ \\
\hline $\begin{array}{l}\text { Finger } \\
\text { pressure }\end{array}$ & $08^{14.62 \pm 4 .}$ & $\begin{array}{l}47.95 \pm \\
3.62\end{array}$ & $4.16^{* *}$ \\
\hline $\begin{array}{l}\quad \text { Intake of } \\
\text { chacha } \\
\text { mushroom }\end{array}$ & $6 \begin{array}{ll}17.38 \pm 03 \\
6\end{array}$ & $\begin{array}{l}41.27 \pm \\
7.84\end{array}$ & $2.73^{-}$ \\
\hline $\begin{array}{l}\text { A half hour's } \\
\text { sunshine }\end{array}$ & $52 \quad$ & $\begin{array}{l}49.86 \pm \\
1.50\end{array}$ & $1.84 * *$ \\
\hline $\begin{array}{c}\text { Toe } \\
\text { acupressure }\end{array}$ & $744^{20.49 \pm 3 .}$ & 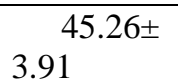 & $\begin{array}{c}- \\
3.52 * *\end{array}$ \\
\hline $\begin{array}{l}\text { Exercise of } \\
\text { muscle }\end{array}$ & 912 & 4.63 & $\begin{array}{c}- \\
5.19^{* *}\end{array}$ \\
\hline
\end{tabular}




\begin{tabular}{|l|l|c|c|}
\hline $\begin{array}{l}\text { Drinking } \\
\text { a goji berry }\end{array}$ & $95^{11.63 \pm 3 .}$ & $3^{36.86 \pm}$ & $\begin{array}{c}- \\
1.63^{* *}\end{array}$ \\
\hline \multicolumn{4}{|c|}{$* \mathrm{p}<.05 * * \mathrm{p}<.01$} \\
\hline
\end{tabular}

\subsection{Changes in the Patient's Physical Condition}

Figure2 shows the physical health conditionsbeforeand after application of the information system. Liver disease has decreased since the 6th day of application of information system applied information system. However, liver disease has been on the rise again since the 18th

Fig. 2 Changes in the patient's physical condition before and after the application of medical information

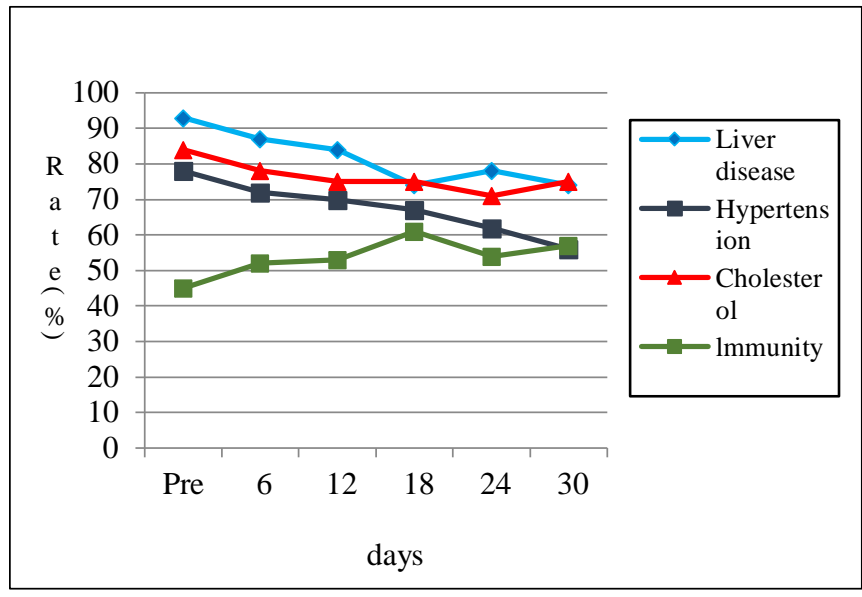

system

\section{Discussion}

This study measures the effectiveness of the medical information system for the treatment of hepatitis B virus. As a result of this study, the condition of liver disease has been significantly reduced since the application of the information system. This is similar to the study of cirrhosis in prior researches[8],[9]. Excessive alcohol consumption, stress and westernized eating habits, etc. are being exposed to liver diseases. Especially, to prevent liver viruses, people should eat good food for their liver, such as bill berry, pineapple. This was similar to the previous studies in which berries were effective in liver cancer[10].[11]. It is important to use an appropriate information system to improve this liver function.

This contains a lot of anthocyanin and polyphenols, which are effective anti-oxidant enzymes in bilberry, which are effective in improving liver function. According to the results, the immune was strengthened to $10-20 \%$ after the application of the information system. In particular, it was confirmed that eating sprout barley is effective in improving liver. This paper means its influence by accepting a specific strategic performance approach. The findings from the study confirmed that this information system is effective. It has been confirmed that inter-virus disease can be prevented from worsening due to the intervention of the information

\section{Conclusion}

This study analyzes the effectiveness of the application of the medical information system to prevent hepatitis $B$ virus. The change in patient condition was analyzed as t-test following the application of the information system. The results of this study are as follows. First, it was found that eating sprout barley after applying the information system was significantly higher than before the system was applied $(\mathrm{t}=-4.16, \mathrm{p}<.01)$.Liver disease has decreased since the 6th day of application of information system applied information system. However, liver disease has been on the rise again since the $18^{\text {th }}$ This paper means its influence by accepting a specific strategic performance approach. The findings from the study confirmed that this information system is effective.

\section{References}

1. Williams, L. T., Goldstein, S. T., Tufa, J.,Tauilli, S., Margolis, H. S., and Mahoney, F. J. (2003). Long Term Antibody Response to Hepatitis B Vaccination Begniing at Birth and to Subsequent Booster Vaccination, Pediatr lnfect Dis J, . 22(2), 157-163. DOI : 10.1097/01.inf.0000050463.28917.25 1

2. Lee, S. J. (2001). A Study on the Change of HBsAg and Anti HBs Positivies for ARecent 15 year Period in Korea, Korean J Hepatol, .7(3), 299-307.

3. Cho, Y. K.,and Song, B. C. (2012).Prevention of Viral Hepatitis and Vaccination. Ko r e a $n$ J Me $d, \quad 82(2), 123-133$, DOI : 10.3904/kjm.2012.82.2.123 
4. Goudeau, A., Dubois, F., Barin, G., Dubois, M. C.,and Coursaget, P, (2008). Hepatitis B Vaccine: Clinical Trials High Risk Settings in France,Develop Biol Standard, 54 , 267-278.

5. J. H. Na, J. H., Cho, H. M., Chung, K. T., Woo. S., Choi, Park, M. J., and Sohn, S. J. (2006), SeroPrevalence of Hepatitis B Virus in University Students,J. Agri M e d \& Community Health, 31(3), 245-253.

6. Song, S. M., Oh, W. 1., and Kim, D. W. (2002). Evaluationof Serologic Marker Tests for Hepatitis B ViralInfection Using the Automated Immunoassay SystemARCHITECT i2000. Korean J Clin Pathol, 22(1), 42-46.

7. Sim, J. G., Seo, J. K. and Suh, S. J. (1995). Prevalence and lts Changes of Hepatitis B Viral Markers from 1988 to1993 in Korean Children. J Korean Pediatr Soc, 38(11)1535-1539.

8. Lee, S. J (2001). A Study on the Change of HBsAgand Anti HBs Positivies for A Recent 15 Year Period inKorea,Korean J Hepatol, 7(3), 299-307.

9. Lee, M. H. (2015). The Positive Rates of Anti-HBs andTiters of Antibody after Hepatitis B Vaccination, Korean J Clin Lab Sci, 47(2), 78-82.DOI : 10.15324/kjcls.2015.47.2.78

10. Jeong, S., Yim, H. W., Bae, S. H., and Lee, W. C. (2008).Changes of Hepatitis B Surface Antigen Seroprevalencein Korea, 1998-2005. Korean J Epidemiol, 30(1),119-127.DOI : 10.4178/kje.2008.30.1.119

11. Jilg, W., SChmit, M.,andDeinhard, F. (2008). Persistenceof Specifics Antibodies After Hepatitis B Vaccination,Jhepatology, 6(2), 201-207.

12. McFarlane, I. D., Jones, P. J., Park, J. R., \& Tranter, R. B. (2018). Identifying GM crops for future cultivation in the EU through a Delphi forecasting exercise. AgBioForum, 21(1), 35-43.

13. Brzica, N. (2018). Understanding Contemporary Asymmetric Threats. Croatian International Relations Review, 24(83), 34-51. 